\title{
Analisis Strategi Optimalisasi Portofolio Saham LQ 45 (pada Bursa Efek Indonesia Tahun 2009-2011)
}

\author{
Dwi Larasati \\ Departemen Manajemen, Fakultas Ekonomi dan Manajemen \\ Institut Pertanian Bogor \\ Kampus Dramaga Bogor 16680 \\ Abdul Kohar Irwanto \\ Departemen Manajemen, Fakultas Ekonomi dan Manajemen \\ Institut Pertanian Bogor \\ Kampus Dramaga Bogor 16680 \\ Yusrina Permanasari \\ Departemen Manajemen, Fakultas Ekonomi dan Manajemen \\ Institut Pertanian Bogor \\ Kampus Dramaga Bogor 16680 \\ e-mail: yusrina.p@gmail.com
}

\begin{abstract}
Capital market is a meeting place for people who have excess money and those who need money for transaction of security. Every investor needs optimal profits with minimal risk. Portfolio is basically related to how one allocates a number of stocks into various investment types that results in optimal profits. By making diversification, investors may reduce the rate of risk and at the sametime optimize the rate of expected return. Based on this case this research raises the problem of how to design an optimal portfolio simulation. i.e. a combination of liquid shares LQ 45 list ini Indonesian Stock Exchange in the period of 2009-2011 by using two methods, using Single Index Model and Indexing. Single index Model is a model of portfolio analysis using the account of Excess Return to Beta (ERB) ratio and value of $C^{*}$ to gain optimal shares on portfolio. The procedure of indexing is to make one's own group i.e liquid LQ 45 calculating the risk and return then compare the result with Single Index Model, the procedure of all securities are ranked by ERB instead of Excess Return to Risk (ERR). After securities were ranked using the above ratio, securities with greater Excess return to standart deviation and cut off point ( $\left.C^{*}\right)$ were included into the optimal portfolio. The conclusion of this research is that it is better to choose Single Index Model as the methode resulting in optimal profits.

Keyword: Optimum portfolio, LQ 45, single index, indexing
\end{abstract}

\begin{abstract}
ABSTRAK
Pasar modal adalah pertemuan antara pihak yang memiliki kelebihan dana dan pihak yang membutuhkan dana melalui jual beli sekuritas (surat berharga). Setiap investor membutuhkan dan menghendaki sejumlah keuntungan yang optimal dengan resiko yang minimal. Penerapan konsep portfolio pada dasarnya dikaitkan dengan bagaimana seseorang (investor) mengalokasikan (menginvestasikan) sejumlah dananya pada instrumen pasar modal yang terdiri dari beberapa jenis surat berharga (diversifikasi) dengan tujuan agar hasil keuntungannya (return) optimal. Melalui strategi diversifikasi, para investor dimungkinkan mampu menekan tingkat resiko dan pada waktu yang sama mampu mengoptimalkan tingkat keuntungan yang diharapkan (Expected Return). Berdasarkan uraian di atas, maka penelitian ini mengangkat masalah bagaimana merancang suatu simulasi penetapan struktur portfolio optimal, misal suatu kombinasi dari saham-saham liquid (blue chips) yang tergabung dalam
\end{abstract}


kelompok index saham LQ 45 yang terdaftar di Bursa Efek Indonesia (BEI). Simulasi didasarkan pada data dalam kurun waktu 2009-2011 dengan menggunakan dua metode, yaitu Model Index Tunggal (Single Index Model, SIM) dan Model Indexing (MI). SIM dalah model analisis portfolio dengan menggunakan akun ERB Ratio dan Cut off Point ( $\left.C^{*}\right)$ mendapatkan susunan struktur saham yang optimal dalam portfolio. Sedangkan prosedur MI memberikan peluang kepada investor membuat kelompok sahamnya sendiri (Misal: LQ 45) melalui perhitungan risk dan return. Selanjutnya hasil dari MI dibandingkan dengan hasil dari SIM, dan semua saham di-rangking berdasarkan nilai ERB Ratio daripada nilai ERR Ratio. Setelah pe-rangking-an terhadap surat berharga tersebut, maka surat berharga yang memiliki Excess Return lebih besar daripada SD dan C* dikelompokan ke dalam portfolio optimal. Kesimpulan dari studi ini adalah bahwa SIM merupakan model yang baik dipilih sebagai metode yang menghasilkan keuntungan optimal.

Kata kunci : portfolio optimal, LQ 45, index tunggal, indexing.

\section{Pendahuluan}

Pasar modal adalah pasar untuk berbagai instrumen keuangan jangka panjang yang bisa diperjualbelikan, baik dalam bentuk hutang maupun modal sendiri, baik yang diterbitkn oleh pemerinth, public authorities, maupun perusahaan swasta (Husnan 2003). Menurut Ahmad (2004), investasi adalah menempatkan uang atau dana dengan harapan untuk memperoleh tambahan atau keuntungan tertentu atas uang atau dana tersebut. Terjadinya penurunan Bank Indonesia (BI) Rate yang pada tahun 2008 sebesar $8-9 \%$ menjadi 6-6,5\% di tahun 2011, berdampak pada penurunan nilai suku bunga bank. Penurunan ini memicu masyarakat untuk menginvestasikan dananya di pasar modal dibanding menyimpan di bank. Memang investasi di pasar modal menjanjikan tingkat keuntungan yang lebih tinggi dibanding hanya menyimpan dana di bank, akan tetapi diiringi dengan tingkat risiko yang tinggi pula. Risiko yang harus ditanggung investor berbanding lurus dengan keuntungannya (Husnan 2003).

Salah satu karakteristik investasi pada pasar modal adalah kemudahan untuk membentuk portofolio investasi. Pembentukan portofolio merupakan kegiatan membagi berbagai jenis usaha, dalam hal ini investasi, yang berarti juga membagi risiko investasi. Pada pembentukan portofolio saham terdapat dua macam strategi yang dapat diterapkan oleh investor, yaitu strategi aktif dan strategi pasif. Pada strategi aktif dilakukan pemilihan saham, rotasi sektor, dan strategi momentum. Sedangkan strategi pasif dapat diterapkan dengan strategi beli simpan atau mengikuti indeks saham.

Dalam teori portofolio dikenal istilah portofolio optimal yang merupakan portofolio yang dipilih investor dari sekian banyak pilihan yang ada pada portofolio efisien (Tandelilin 2001). Pada pembentukan portofolio optimal terdapat banyak metode yang dapad digunakan, salah satunya Model Indeks Tunggal (MIT). MIT merupakan penyederhanaan Index Model yang dikembangkan oleh Markowitz. MIT menjelaskan hubungan antara return dari setiap sekuritas individual dengan return indeks pasar, didasarkan pada pengamatan bahwa harga suatu saham berfluktuasi searah dengan indeks harga pasar (Jogiyanto 2010).

Penelitian ini menggunakan MIT sebagai strategi aktif dan metode mengikuti indeks sebagai strategi pasif. Saham-saham yang digunakan dalam penelitian ini adalah yang terdaftar pada Indeks LQ 45. Indeks ini terdiri dari 45 saham di BEI dengan likuiditas yang tinggi dan kapitalisasi pasar yang besar, menguasai hingga $70 \%$ pemilikan modal 
saham di pasar dan nilai transaksi pada pasar biasa, serta lolos seleksi menurut beberapa kriteria pemilihan.

Tujuan penelitian ini adalah: (1) Menganalisis komposisi portofolio optimal menggunakan MIT saham Indeks LQ 45 di BEI, (2) Menganalisis kinerja portofolio optimal menggunakan MIT saham Indeks LQ 45 di BEI, (3) Menganalisis perbandingan kinerja portofolio optimal saham Indeks LQ 45 strategi aktif menggunakan MIT dengan strategi pasif mengikuti indeks pasar.

\section{Metode Penelitian}

Portofolio saham merupakan sekelompok saham yang dimiliki pemilik atau pengelola dana investasi. Pada tahap awal pengambilan keputusan, investor perlu menetapkan tujuan serta batasan risiko dalam berinvestasi. Setelah investor menetapkan Expected Return (ER) serta risiko yang akan ditanggungnya, tahap berikutnya adalah melakukan pengukuran kinerja portofolio tersebut, dalam penelitian ini menggunakan MIT. Selanjutnya, hasil pengukuran kinerja portofolio menggunakan MIT dibandingkan dengan kinerja portofolio saham-saham mengikuti Indeks LQ 45 untuk melihat portofolio mana yang memiliki kinerja lebih baik. Kerangka pemikiran penelitian ini dapat dilihat pada Gambar 1.

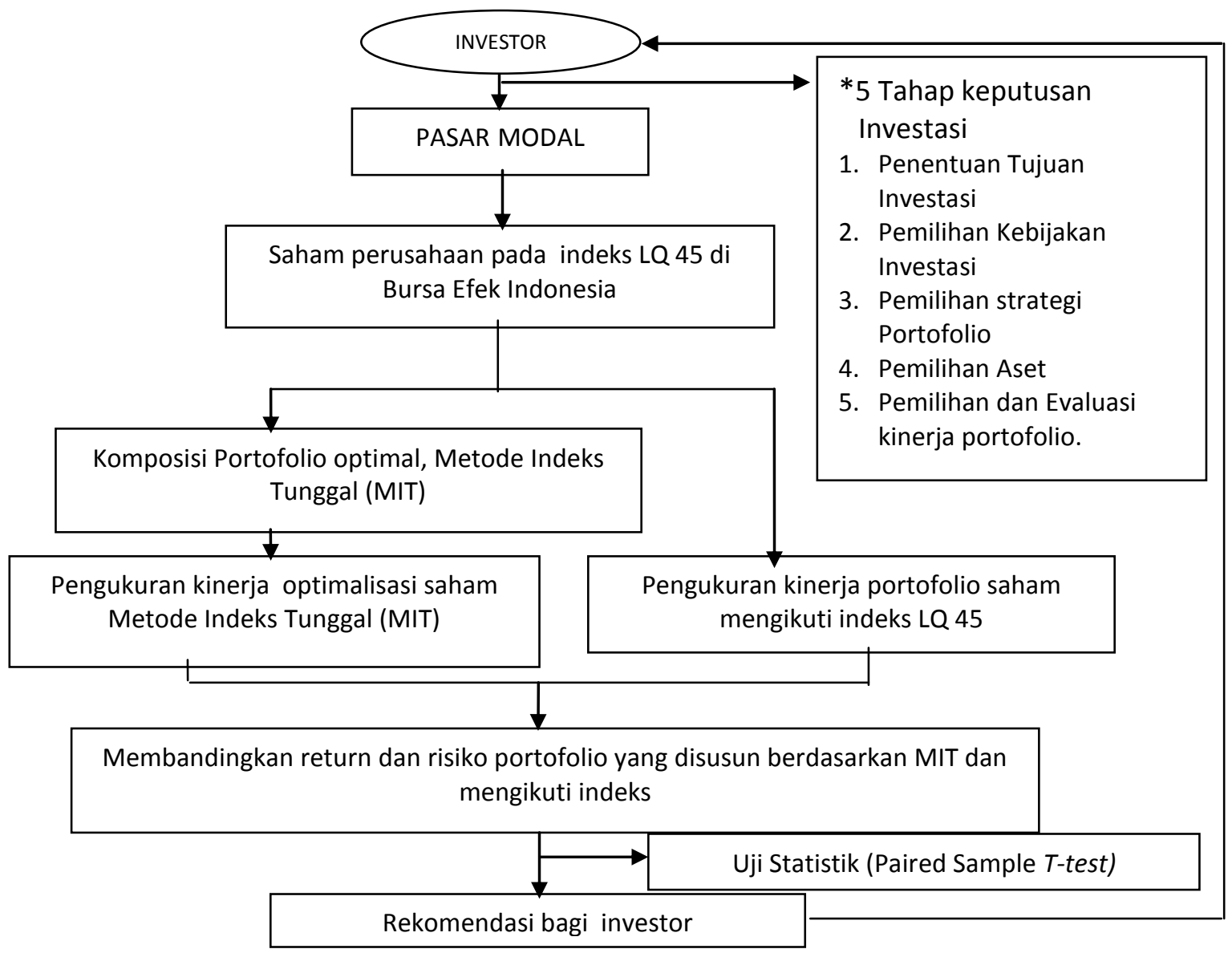

Gambar 1. Kerangka Pemikiran Penelitian 
Perhitungan MIT didasarkan pada ERB yang berasal dari prinsip ratio Treynor pada Capital Asset Pricing Model (CAPM). Metode ini mengukur kinerja portofolio dari besarnya return premium yang dihasilkan oleh setiap unit risiko sistematis. ERB mengukur kelebihan return relatif terhadap satu unit risiko yang tidak dapat didiversifikasi yang diukur dengan beta. ERB menentukan saham-saham yang dapat dimasukan ke dalam portofolio. Excess return sendiri didefinisikan sebagai selisih ER dengan return aktiva bebas risiko yang pada penelitian ini menggunakan nilai Sertifikat Bank Indonesia (SBI).

Saham-saham yang akan masuk ke dalam portofolio diseleksi dengan mengeluarkan saham-saham yang memiliki nilai ERB lebih kecil dari Unique Cut Off Point (UCOP), karena saham-saham tersebut dianggap memiliki tingkat kepekaan return yang tidak terlalu signifikan terhadap perubahan return pasar. Perhitungan nilai ERB masingmasing saham adalah sebagai berikut:

$$
E R \beta i=\frac{E R i-R f}{\beta i} \ldots \ldots \ldots \ldots \ldots \ldots \ldots \ldots \ldots
$$

Di mana :

$$
\begin{array}{ll}
\mathrm{ER} \beta & =\text { excess return to beta saham } \mathrm{i} \\
\mathrm{Rf} & =\text { return aktiva bebas risiko ( } \mathrm{SBI} \text { ) } \\
\mathrm{Bi} & =\text { beta saham } \mathrm{i}
\end{array}
$$

Berikutnya adalah menghitung nilai Ai dan Bi yang diperlukan untuk menentukan nilai cut off point:

$$
\begin{aligned}
& A i=\frac{[E R i-R f] \beta i}{\sigma^{2} e_{i}} . \\
& B i=\frac{\beta i^{2}}{\sigma^{2} e_{i}} . \\
& C i=\frac{\sigma^{2} m{ }_{i=1}^{n} A j}{1+\sigma^{2}{\underset{i=j}{n} B j}_{n}^{n}}
\end{aligned}
$$

Di mana :

$C_{i}=$ nilai $C$ untuk saham $i$ yang dihitung dari kumulasi nilai $A_{1}$ sampai dengan nilai $A_{i}$ dan nilai $B_{1}$ sampai dengan nilai $B_{i}$

Besarnya UCOP $\left(C^{*}\right)$ adalah nilai $C_{i}$ yang terbesar. Saham-saham yang dimasukkan untuk membentuk portofolio optimal adalah saham-saham yang mempunyai nilai ERB lebih besar atau sama dengan nilai $C^{*}$. Setelah menghitung proporsi masing-masing saham tersebut pada portofolio optimal, kemudian dihitung nilai ER, standar deviasi (risiko), dan kovarians portofolio. Dilanjutkan dengan penentuan kinerja portofolio mengikuti indeks dengan menghitung return indeks LQ 45 ( $\left.R_{i t}\right)$ selama periode pengamatan. 
Hipotesis yang diajukan dalam penelitian ini yaitu:

1. $\mathrm{H}_{0}=0$ (Tidak terdapat perbedaan dalam hal return dan risiko antara portofolio saham strategi aktif dan portofolio saham strategi pasif).

2. $\mathrm{H}_{1} \neq 0$ (Terdapat perbedaan dalam hal return dan risiko antara portofolio saham strategi aktif dan portofolio saham strategi pasif).

Kriteria pengujian yang digunakan adalah:

Tolak $\mathrm{H}_{0} \quad$ : bila $\mathrm{t}_{\text {hitung }}<\mathrm{t}_{\text {tabel }}$

Terima $\mathrm{H}_{1}$ : bila $\mathrm{t}_{\text {hitung }}<\mathrm{t}_{\text {tabel }}$

Prosedur penentuan sampel pada penelitian ini menggunakan teknik non-random sampling metode purposive sampling, yaitu saham yang terus-menerus muncul dalam kelompok LQ 45 di BEI selama kurun waktu 6 periode, dari tahun 2009 sampai dengan tahun 2011.

\section{Hasil Dan Pembahasan}

III.1. Komposisi dan Kinerja Portofolio Menggunakan Metode Indeks Tunggal

Indeks LQ 45 merupakan kelompok saham yang terdiri dari 45 saham di BEI dengan likuiditas yang tinggi dan kapitalisasi pasar yang besar, menguasai hingga $70 \%$ dari pemilikan modal saham di pasar dan nilai transaksi pada pasar biasa, serta lolos seleksi menurut beberapa kriteria pemilihan yang telah ditetapkan (BEI 2011). Berdasarkan kriteria pemilihan yang telah ditetapkan, diperoleh 19 kandidat saham portofolio. Nilai ER, standar deviasi, dan varians masing-masing saham tersebut dapat dilihat pada Tabel 1.

Tabel 1. E(Ri), STDev dan Variance saham individual

\begin{tabular}{ccccc}
\hline No & Kode Saham & $\mathbf{E}(\mathbf{R i})$ & STDev & Variance \\
\hline 1 & AALI & 0,02687 & 0,08406 & 0,00707 \\
2 & UNSP & 0,01771 & 0,19045 & 0,03627 \\
3 & ANTM & 0,01838 & 0,11705 & 0,0137 \\
4 & MEDC & 0,01324 & 0,09986 & 0,00997 \\
5 & PTBA & 0,03243 & 0,10749 & 0,01155 \\
6 & INCO & 0,02321 & 0,14413 & 0,02077 \\
7 & TINS & 0,02089 & 0,13008 & 0,01692 \\
8 & ASII & 0,06207 & 0,10325 & 0,01066 \\
9 & BBCA & 0,03004 & 0,09115 & 0,00831 \\
10 & BBNI & 0,05926 & 0,15532 & 0,02412 \\
11 & BBRI & 0,02356 & 0,14129 & 0,01996 \\
12 & BDMN & 0,1064 & 0,01132 \\
13 & BMRI & 0,01414 & 0,11462 & 0,01314 \\
14 & INDF & 0,04079 & 0,12127 & 0,01471 \\
15 & ISAT & 0,0529 & 0,09667 & 0,00934 \\
16 & PGAS & 0,00497 & 0,09488 & 0,009 \\
17 & TLKM & 0,0213 & 0,06808 & 0,00464 \\
18 & SMCB & 0,0045 & 0,12648 & 0,016 \\
19 & UNTR & 0,04254 & 0,1049 & 0,011 \\
\hline
\end{tabular}


Hasil perhitungan nilai cut-of-point $\left(C^{*}\right)$ pada penelitian ini adalah sebesar 0,017168 dan ERB terbesar bernilai 0,020862. Oleh karena itu, diperoleh 9 saham yang menjadi kandidat portofolio yang dapat dilihat pada Tabel 2.

Tabel 2. Saham kandidat portofolio (ERB $\left.>C^{*}\right)$

\begin{tabular}{cccc}
\hline No & Kode Saham & ERB & $\mathbf{C i}$ \\
\hline 1 & ASII & 0,042236 & 0,017168 \\
2 & UNTR & 0,040288 & 0,015155 \\
3 & AALI & 0,034112 & 0,006238 \\
4 & INDF & 0,032154 & 0,012067 \\
5 & BBNI & 0,030925 & 0,010439 \\
6 & SMCB & 0,029026 & 0,008484 \\
7 & BBCA & 0,027081 & 0,007722 \\
8 & BMRI & 0,021993 & 0,009737 \\
9 & PTBA & 0,020862 & 0,007683 \\
\hline
\end{tabular}

Penelitian ini bertujuan untuk membentuk portofolio optimal dengan memilih saham-saham yang memiliki nilai ERB terbesar. Untuk itu dipilih 5 saham yang memiliki nilai ERB terbesar yang juga berasal dari sektor yang berbeda, sesuai dengan prinsip diversifikasi. Kelima saham tersebut dengan dengan nilai ERB masing-masing adalah Kelima saham tersebut adalah Astra Internasional Tbk (sektor miscellaneous industry, $\left.A S I_{E R B}=0,042236\right)$, United Tractor Tbk (sektor trade, service, and investment, UNTR $=0,040288$ ), Astra Agro Lestari Tbk (sektor agriculture, $A A L I_{E R B}=0,034112$ ), Indofood Sukses Makmur Tbk (sektor consumer goods industry, $I N D F_{E R B}=0,032154$ ), dan Bank Negara Indonesia Tbk (sektor finance, $\mathrm{BNI}_{\mathrm{ERB}}=0,030925$ ). Dari kelima saham tersebut dilakukan perhitungan proporsi dana yang akan diinvestasikan pada masing-masing saham dalam portofolio optimal yang hasilnya dapat dilihat pada Tabel 3.

Tabel 3. Proporsi dana saham pembentuk portofolio

\begin{tabular}{cccc}
\hline No & Kode Saham & $\mathbf{X i}$ & $\mathbf{W i}$ \\
\hline 1 & ASII & 31,4 & $32,08 \%$ \\
2 & UNTR & 26,75 & $27,32 \%$ \\
3 & AALI & 14,9 & $15,29 \%$ \\
4 & INDF & 14,97 & $15,29 \%$ \\
5 & BBNI & 9,88 & $10,09 \%$ \\
\hline
\end{tabular}

Hasil perhitungan ER dan standar deviasi portofolio optimal yang terbentuk dari kelima saham tersebut dapat dilihat pada Tabel 4. 
Tabel 4. E(Rp), STDev portofolio

\begin{tabular}{ccc}
\hline Kode Saham & $\mathbf{E}(\mathbf{R i )}$ & STDev \\
\hline ASII & 0,06207 & 0,10325 \\
UNTR & 0,05696 & 0,1049 \\
AALI & 0,02687 & 0,08406 \\
INDF & 0,0529 & 0,12127 \\
BBNI & 0,05926 & 0,15532 \\
\hline Portofolio & $\mathbf{0 , 0 5 3 6 5}$ & $\mathbf{0 , 0 0 9 2 8}$ \\
\hline
\end{tabular}

Berikutnya adalah menghitung koefisien korelasi dan covariance antarsaham pembentuk portofolio. Hasil perhitungannya dapat dilihat pada tabel 5 dan 6 .

Tabel 5. Koefisien korelasi saham pembentuk portofolio

\begin{tabular}{cccccc}
\hline & ASII & UNTR & AALI & INDF & BBNI \\
\hline ASII & 1 & 0,736 & 0,36 & 0,691 & 0,582 \\
UNTR & 0,736 & 1 & 0,565 & 0,592 & 0,582 \\
AALI & 0,36 & 0,565 & 1 & 0,331 & 0,302 \\
INDF & 0,691 & 0,592 & 0,331 & 1 & 0,645 \\
BBNI & 0,582 & 0,582 & 0,302 & 0,645 & 1 \\
\hline
\end{tabular}

Tabel 6. Covariance saham pembentuk portofolio

\begin{tabular}{cccccc}
\hline & ASII & UNTR & AALI & INDF & BBNI \\
\hline ASII & 0,01 & 0,008 & 0,003 & 0,008 & 0,009 \\
UNTR & 0,008 & 0,011 & 0,005 & 0,007 & 0,009 \\
AALI & 0,003 & 0,005 & 0,007 & 0,003 & 0,004 \\
INDF & 0,008 & 0,007 & 0,003 & 0,014 & 0,012 \\
BBNI & 0,009 & 0,009 & 0,004 & 0,012 & 0,023 \\
\hline
\end{tabular}

Koefisien korelasi adalah suatu ukuran statistik yang menunjukkan pergerakkan bersama relatif antara dua variabel. Dalam konteks diversifikasi, ukuran ini akan menjelaskan sejauh mana return dari satu sekuritas terkait satu dengan yang lainnya. Pada konsep diversifikasi, penggabungan dua sekuritas yang berkorelasi positif sempurna $(+1,0)$ tidak akan memberikan manfaat pengurangan risiko. Penggabungan dua sekuritas yang berkorelasi nol, akan mengurangi risiko portofolio secara signifikan.

Semakin banyak jumlah saham yang tidak berkorelasi dimasukkan dalam portofolio, semakin besar manfaat pengurangan risiko yang diperoleh. Penggabungan dua buah sekuritas yang berkorelasi negatif sempurna $(-1,0)$ akan menghilangkan risiko kedua sekuritas tersebut. Hal ini sejalan dengan prinsip strategi lindung nilai (hedging) terhadap risiko (Tandelilin 2001). Hasil penelitian menunjukkan sekuritas memiliki korelasi positif terhadap sekuritas lainnya, walaupun tidak sempurna (+1). Hal ini menunjukkan bahwa investor tidak dapat menghilangkan sama sekali risiko portofolio, namun yang dapat dilakukannya adalah mengurangi portofolio risiko.

Kovarians adalah suatu aturan absolut yang menunjukkan sejauh mana dua variabel mempunyai kecenderungan untuk bergerak secara bersama-sama. Dalam konteks manajemen portofolio, kovarians menunjukkan sejauh mana return dari kedua sekuritas dalam portofolio cenderung untuk bergerak secara bersama-sama. Kovarians 
bisa berbentuk angka positif, negatif, ataupun nol. Kovarians positif berarti kecenderungan dua sekuritas bergerak ke arah yang sama, kovarians negatif berarti bahwa return dua buah sekuritas cenderung untuk bergerak menuju arah berkebalikan. Jika return sekuritas A naik maka return sekuritas B turun, demikian juga sebaliknya. Sedangan kovarian nol mengindikasikan bahwa pergerakkan dua buah sekuritas bersifat independen satu sama lain.

Hasil penelitian menunjukkan nilai kovarian yang cenderung mendekati nol. Ini mengindikasikan pergerakkan sekuritas cenderung bersifat independen satu sama lain dan cenderung bergerak menuju arah yang berlawanan. Hal ini berarti semakin besar manfaat pengurangan risiko yang diperoleh pada portofolio tersebut.

\section{III.2. Perbandingan Kinerja Portofolio menggunakan MIT dengan Metode Mengikuti Indeks}

Penelitian dilakukan dengan pembentukkan portofolio strategi pasif dengan cara membentuk portofolio yang mirip dengan indeks pasar, dalam hal ini yaitu saham pada Indeks LQ 45 tahun 2009-2011. Metode yang disebut sebagai index fund ini mendapatkan ER sebesar 0,028 dengan varians (expected risk) sebesar 0,004. Berdasarkan perbandingan dengan pembentukan portofolio strategi aktif menggunakan MIT, strategi pasif metode mengikuti indeks memiliki nilai expected return yang lebih kecil, sementara varians atau risikonya lebih besar dari pendekatan strategi aktif. Hal ini sepadan dengan upaya strategi aktif dalam mencari informasi dan menganalisis informasi dibandingkan dengan hanya mengikuti indeks.

Pengujian dilakukan dengan cara mengelompokkan rata-rata return dan risiko saham menjadi dua kelompok, yaitu kelompok saham pendekatan strategi aktif MIT dan kelompok saham metode pasif mengikuti indeks LQ 45. Kedua kelompok sampel dibandingkan dan dilakukan pengujian dengan kriteria pengujian didasarkan pada tingkat signifikansi dengan menggunakan metode Paired-Samples $T$ Test. PairedSamples $T$ Test merupakan prosedur yang digunakan untuk membandingkan rata-rata dua variabel dalam satu kelompok.

Berdasarkan hasil uji yang ditunjukkan pada Tabel 7, diketahui bahwa return saham kelompok strategi aktif dan kelompok strategi pasif memiliki perbedaan yang signifikan. Angka signifikansi t hitung sebesar 0,003 $<0,05(\alpha=5 \%)$. Hasil tersebut menunjukkan terdapat perbedaan return yang signifikan antara pendekatan strategi aktif dengan strategi pasif (tolak $\mathrm{H}_{0}$, terima $\mathrm{H}_{1}$ ). Untuk perbedaan risiko diukur dengan standar deviasi yang mencerminkan risiko total saham. Hasil perhitungan menunjukkan angka signifikansi sebesar $0,0437<0,05(\alpha=5 \%)$ yang artinya tolak $\mathrm{H}_{0}$ terima $\mathrm{H}_{1}$. Hasil tersebut mengindikasikan adanya perbedaan yang signifikan antara portofolio strategi aktif Metode Indeks Tunggal dengan portofolio strategi pasif mengikuti Indeks LQ 45. 
Tabel 7. Hasil uji statistik metode Paired-Samples T Test

\begin{tabular}{|c|c|c|c|c|c|c|c|c|c|}
\hline & & \multicolumn{5}{|c|}{ Paired Differences } & \multirow[t]{3}{*}{$\mathbf{t}$} & \multirow[t]{3}{*}{ df } & \multirow{3}{*}{$\begin{array}{l}\text { Sig. (2- } \\
\text { tailed) }\end{array}$} \\
\hline & & \multirow[t]{2}{*}{ Mean } & \multirow[t]{2}{*}{$\begin{array}{c}\text { Std. } \\
\text { Deviation }\end{array}$} & \multirow[t]{2}{*}{$\begin{array}{l}\text { Std. } \\
\text { Error } \\
\text { Mean }\end{array}$} & \multicolumn{2}{|c|}{$\begin{array}{l}\text { 95\% Confidence } \\
\text { Interval of the } \\
\text { Difference }\end{array}$} & & & \\
\hline & & & & & Upper & Lower & & & \\
\hline $\begin{array}{c}\text { Pair } \\
1\end{array}$ & $\begin{array}{c}\text { saham_portofolio } \\
\text {-LQ_45 }\end{array}$ & 0,024 & 0,043785 & 0,007 & 0,008954 & 0,038584 & 3,257 & 35 & 0,003 \\
\hline
\end{tabular}

\section{Kesimpulan}

Pembentukan portofolio optimal menggunakan Model Indeks Tunggal terhadap 19 saham-saham sampel penelitian, terdapat 9 saham yang mempunyai nilai ERB lebih besar dari UCOP. Penelitian ini memilih 5 saham yang memiliki nilai ERB terbesar dan mewakili sektor berbeda sebagai saham-saham pembentuk portofolio optimal. Kelima saham tersebut adalah Astra Internasional Tbk (sektor miscellaneous industry), United Tractor Tbk (sektor trade, service, and investment), Astra Agro Lestari Tbk (sektor agriculture), Indofood Sukses Makmur Tbk (sektor consumer goods industry), dan Bank Negara Indonesia Tbk (sektor finance).

Kinerja portofolio saham dari strategi aktif MIT menunjukkan hasil ER portofolio sebesar 0,05365 dengan tingkat risiko 0,00928. Sementara kinerja portofolio saham berdasarkan strategi pasif Mengikuti Indeks LQ 45 diperoleh ER sebesar 0,028 dengan tingkat risiko sebesar 0,004.

Hasil analisis statistik dengan metode Paired-Samples $T$ Test diketahui bahwa return kelompok saham strategi aktif dan kelompok saham strategi pasif memiliki pebedaan yang signifikan. Angka signifikansi t hitung sebesar 0,003 $<0,05(\alpha=5 \%$ ). Untuk perbedaan risiko diukur dengan standar deviasi yang mencerminkan risiko total saham. Hasil perhitungan menunjukkan angka signifikansi sebesar 0,0437<0,05 $(\alpha=$ $5 \%$ ) yang mengindikasikan adanya perbedaan yang signifikan antara risiko portofolio strategi aktif Metode Indeks Tunggal dengan portofolio strategi pasif mengikuti Indeks LQ 45.

\section{Daftar Pustaka}

Ahmad K. 2004. Dasar-dasar Manajemen Investasi dan Portofolio. Jakarta(ID): Rineka Cipta.

[BEI] Bursa Efek Indonesia. 2011. IDX Fact Book 2011. Jakarta (ID): BEI.

Husnan S. 2003. Dasar-dasar Teori Portofolio dan Analisis Sekuritas. Edisi Ketiga. Yogyakarta (ID): Unit Penerbit dan Percetakan AMP YKPN.

Jogiyanto. 2010. Dasar-dasar Teori Portofolio dan Analisa Sekuritas. Edisi ketujuh. Yogyakarta (ID): BPFE.

Tandelilin E. 2001. Analisis Investasi dan Manajemen Portofolio. Edisi Pertama. Yogyakarta (ID): BPFE 